\title{
Human Capital and Economic Growth in Nigeria: Does Life Expectancy and Schooling Matter?
}

\author{
Ogunbadejo, HussainKehinde ${ }^{1} \quad$ Kanwanye, Hilary Temofeh $(\mathrm{PhD})^{2}$ \\ 1.Nigerian Institute for Oceanography \& Marine Research, Victoria Island Lagos \\ 2.Department of Economics, University of Benin, Benin-City
}

\begin{abstract}
This paper examines the economic growth effect of human capital in Nigeria using annual time series dataset spanning 1970 to 2017. Life expectancy and schooling were the human capital components considered while the growth rate of Gross Domestic Product captures economic growth. The Two-Stage Least Squares approach was adopted in the analysis after testing for unit root and cointegration among variables. Results indicate that both physical and human capital exerts a significant positive impact on economic growth in Nigeria. Specifically, life expectancy, secondary and tertiary school enrolments - components of human capital - significantly spur economic growth while primary school enrolment and average years of schooling have no significant effect on the economic growth of the country. The paper recommends, amongst others, that all levels of government should raise the percentage of health and education funds in their financial disbursement for optimal performance of the economy.
\end{abstract} Keywords: Life expectancy, Schooling, Human Capital, Economic Growth, Two-Stage Least Squares.

DOI: $10.7176 / \mathrm{JESD} / 11-16-10$

Publication date:August $31^{\text {st }} 2020$

\section{Introduction}

In this era of the knowledge economy, the key to international competition is high-quality human capital. The knowledge economy addresses how education and knowledge, that is, "human capital," can serve as a productive asset or business product to be sold and exported to yield profits for individuals, businesses, and the economy. This component of the economy relies greatly on intellectual capabilities instead of natural resources or physical contributions. In the knowledge economy, products and services that are based on intellectual expertise advance technical and scientific fields, encouraging innovation in the economy as a whole.

Nigeria, as the most populous country in Africa, to improve its high-quality human capital, needs to settle primary problem first - to decide what kind and which level of education should be the priority of the education development strategy, considering her current limited resources. In theory, education can improve labour quality, drive the spread of new knowledge and improve labour's ability to introduce, imitate and apply advanced technologies, however, the conclusion of empirical research is uncertain(Temple, 2001).

One fundamental component of human capital is education. And one of the major proxies for measuring education in the literature is the gross total tertiary school enrolment rate. Unfortunately, the gross tertiary school enrolment rate has been fluctuating, experiencing increases at a very slow pace. For instance, in 1970, the gross tertiary school enrolment rate stood at $0.13 \%$; it was $1.83 \%$ in 1980 , while as of 1990 , it was $4.28 \%$. It rose to $7.45 \%$ in 2000 and by 2013, the gross tertiary school enrolment rate was $13.40 \%$ (Nigerian Bureau of Statistics, 2017). The 2017 Human Development Report ranked Nigeria 157 out of 189 countries, with a Human Development Index of 0.532 . Health is another main component of human capital. Health is measured by several indicators with the most common being life expectancy, infant mortality and the fertility rates. Increased life expectancy brings about changes in expenditure and savings decisions, as well as increases savings rates which in turn, boost investment and economic growth rates (Ogundari and Awotuse, 2018). Health can impact economic growth indirectly via education, where healthier children tend to have higher school attendance rates, hence, improving the overall quality of the labour force, as well as promoting output. In this manner, health and economic growth are interrelated. Better health, according to Mayer-Foulkes(2001), increases workforce productivity and wages by reducing incapacity, debility, and the number of days lost to sickness.

By possessing the ability to produce and use equipment and technology, human beings have become the most important and promising sources of economic growth and productivity. As such, any successful productive program is dependent on human innovative ideas and creativity. According to Romer (1986) and Lucas (1988), in recent times, human capital development and its impact on economic growth emphasized the growth theory. In their works, these authors posit that in the long run, output per unit of input can increase even when inputs are exhaustively accounted for.

Education remains a potent tool for self-reliance and national development in Nigeria. Studies like Ekanem (2012) sees education as a potent instrument with which the problem of national development can be successfully dealt with, while Dauda (2009) carried out an empirical investigation on the relationship between investment in education and economic growth in Nigeria which showed that education or human development is at the core of every socio-economic development programme of any nation. Several challenges are confronting the education 
sector in Nigeria. These include academic staff shortages in the critical areas of Science and Technology. In addition to these human capacity gaps, there are also the challenges associated with education quality and insufficient investments to keep pace with Nigeria's growing school-age population. The challenges associated with the education sector, particularly in higher education, has led to an increased number of Nigerians going abroad in pursuit of better education standards. For instance, according to the United States Embassy in Nigeria in 2017, Nigeria remains the largest source of students from sub-Saharan Africa to the United States. As of January 2016, there was a total of 11,710 Nigerian students studying in over 733 regionally accredited U.S colleges and universities. Also, 17,973 Nigerians were studying in United Kingdom universities (Institute of International Education, 2017).

As of 2016, Nigeria is ranked as having the highest number of out of school children in the world. According to the United Nations International Children's Fund (UNICEF, 2015), 13.2 million Nigerian children are out of school. Even though primary education is officially free and compulsory, Only 61 per cent of 6-11 year-olds regularly attend primary school and only 35.6 per cent of children aged 36-59 months receive early childhood education. Furthermore, there are regional variations as the percentage of the population that attended schools in the year 2015 was higher in urban areas (91.4\%) than in rural areas with $80.7 \%$. Also, gender variation still exists in school attendance in Nigeria. In the aforementioned year, females' attendance stood at $81.2 \%$, lower than that of males' with $88.1 \%$.

The life expectancy of the nation from 1960 till date has increased just marginally. For instance, it has ranged between 36 years in 1960 and 48years in 2009. And the average years from 2000 to 2017 was 51.9 years (World Development Indicator, 2017). This indicates that the Nigerian life expectancy has not witnessed much improvement not even with the level of health expenditures over the years. It is on this note that the question becomes relevant of whether health as a component of human capital matters for the growth of the economy of Nigeria? Government expenditure on health seems to have little impact on life expectancy considering its low level since independence. Mortality and morbidity rates among both adults and children have continued to steer the country in the face. Yet, the economy has persisted to record high growth rate. The two-way causality that exists between income level and health status is expected to have led to the improved health status of the Nigerian population considering the level of growth of the nation's Gross Domestic Product (GDP) since theoretically, health as an outcome is influenced by income level and conversely health status influences the level of income. The case of Nigeria seems to be paradoxical; this is because as the level of her GDP increases, so also communicable diseases as well as morbidity and mortality within the economy, increase.

Since the existing empirical results are paradoxical, a further and deeper examination on the relationship between human capital and economic growth is extremely necessary. Besides, as a country, the investment in education is subject to resource constraints, therefore, we need to set up the investment priorities of all levels of education. Thus, studies that explore the effect of different level of education on economic growth is needed. This article analyzed the impact of education on economic growth by constructing a theoretical model where health, education and other factors that affect economic growth are also introduced. Thus, these questions are pertinent: What is the relationship between education and economic growth? What kind of education makes the largest contribution to economic growth? What is the impact of life expectancy on economic growth? This paper seeks to answer these questions, among others, and further investigate the three different impacts of primary, secondary and higher education on economic growth.

This paper is structured into six sections. Following the introductory section are trends of selected variables. The third section presents a review of literature while the fourth discusses the methodology adopted. Results obtained were provided in the fifth section while the sixth section concludes the paper.

\section{Trends of the Selected Variables}

\subsection{Gross Domestic Product Growth Rate from 1970-2017 in Nigeria}

The government of Nigeria tried to pull itself together through a program of "reconstruction" of the war-torn area, and improvement in the standard of living of its citizens immediately after the civil war. Luckily, the 25 percent growth rate was facilitated by oil resources which formed the bedrock of the needed growth and development. As Nigeria benefitted from oil shocks of the 1970s, the first of which brought about a quadrupling of the price level. The average growth rate of gross domestic product from 1971-74 was 8.5 percent and it was as a result of increasing federal revenue from oil which constituted 80 percent of total revenues (Bhatia \&Engström,1972). Nigeria's GDP growth rate of 11.2 percent in 1974 dropped considerably, and at the end of 1980, it was 4.2 percent. The reason for the fall in the growth rate of the gross domestic product can be attributed to the first crash in the oil market in 1978. The rise in the price of petroleum in 1979 was misconstrued to be an assurance of hope, but it was short-lived by worsening oil price conditions experienced in the 1980s. 


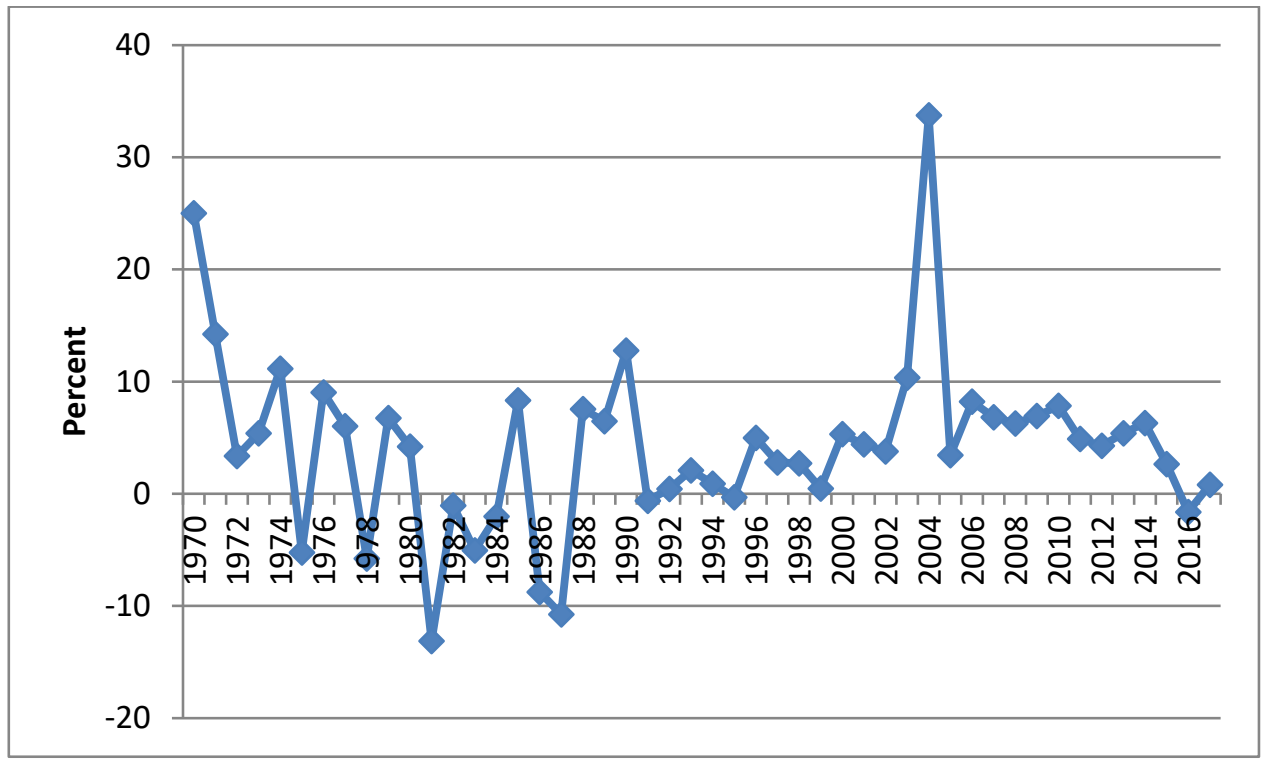

Figure 1: GDP Growth Rate in Nigeria, 1970-2017.

Source: World Bank Development Indicators, 2018

Figure 1 displays Nigeria's GDP growth rate from 1970 through 2017. In 2017, GDP growth for Nigeria was $0.8 \%$. Nigeria's GDP growth fluctuated substantially over the period. It tended to decrease through $1998-2017$ period ending at $0.8 \%$ in 2017. In 2016, Nigeria experienced its first full year of recession in 25 years. Global oil prices reached a 13-year low and oil production was crushed by vandalism and militant attacks in the Niger Delta, resulting in severe contraction of oil GDP. While the oil sector represented only 8.4 percent of GDP, the low foreign exchange earnings from oil exports had significant spillover effects on non-oil sectors, especially industry and services, which are dependent on imports of inputs and raw materials. Compounded by inadequate policy responses, these challenges caused the overall real GDP to contract by 1.5 percent.

\subsection{Human Capital}

Human capital refers to investments made on humans which have an ultimate effect on the economic growth of a country. Like physical capital - which are investments on buildings, equipment, machines and raw materials, human capital has a positive influence on GDP, There is also a positive association between human capital and the level of investment in education with growth (Keller, 2006; McMahon, 1998). Benhabib and Spiegel (1994) argued that a source of economic growth is human capital development. Gemmell (1996) argued that the determinants of economic growth are both human capital and their growth rates. It is a key factor that has a major contribution to the economic development of countries. Therefore, human capital is positively related to to the GDP of a nation and its components are the health and education status of humans.

\subsection{Life Expectancy in Nigeria}

Life expectancy at birth indicates the number of years a newborn infant would live if prevailing patterns of mortality at the time of its birth were to stay the same throughout its life. It is an indicator of the health status of people. Nigeria has a world life expectancy ranking of 157 out of 192 ranked countries. However, a report by the Nigerian Bureau of Statistics (NBS) for 2017 has it that females can live for approximately 51 years while males can live for just 47 years. It was also reported that residents in Nigeria are liable to die of sicknesses and diseases, as well as other causes. Causes of death listed in the report are influenza, pneumonia, tuberculosis, diarrhoeal diseases, stroke, HIV/AIDS, coronary heart disease, liver disease, prostate cancer, diabetes mellitus, maternal conditions, malaria, breast cancer, meningitis, cervical cancer, lung disease and low birth weight. Other causes include accident, road traffic nuances and birth trauma among others. 


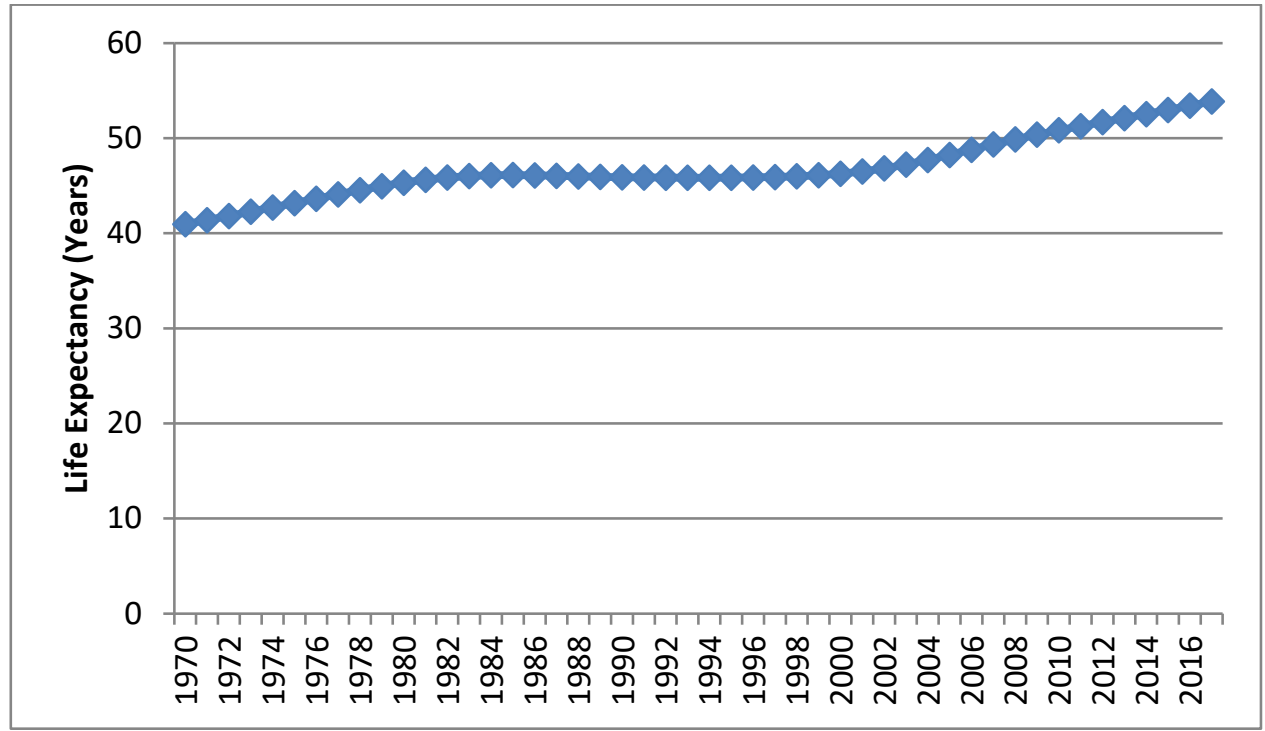

Figure 2: Life Expectancy in Nigeria, 1970-2017.

Source: Human Development Index, 2018/

Figure2 shows the trend in life expectancy in Nigeria from 1970 to 2017 . The average value for Nigeria during the period was 46.82 years with a minimum of 40.96 years in 1970 and a maximum of 53.95 years in 2017 . It indicates that life expectancy in Nigeria increased from 40. 96 years in 1970 to 53.95 years in 2017. It grew at an average annual rate of 0.6 percent.

\subsection{Education in Nigeria}

Education includes the activities of getting or acquiring general knowledge. It involves the learning process of basics skills such as mathematics, geography and also developing an elementary understanding of some other subjects e.g., history, natural sciences, social sciences, art and Arabic, developing reasoning and judgmental mental power, and preparing oneself or others intellectually for mature life. School enrollment, primary (\% gross), school enrollment, secondary (\% gross) and school enrollment, tertiary (\% gross) have been considered as proxies for primary, secondary and tertiary education, respectively (Loening, 2005). Barro (1991) argued that there is a significant and positive association between economic growth and education. Bils and Klenow (2000) argued that high enrollment rate causes rapid improvement in productivity; therefore, faster growth in per capita income (PCI) resulted in countries where there is a high rate of enrollment in schools. Hanushek and Kimko (2000) argued that there is a remarkable increase in productivity and national growth rates due to the quality of education. Thus, education is a significant primary input factor for the growth of an economy.

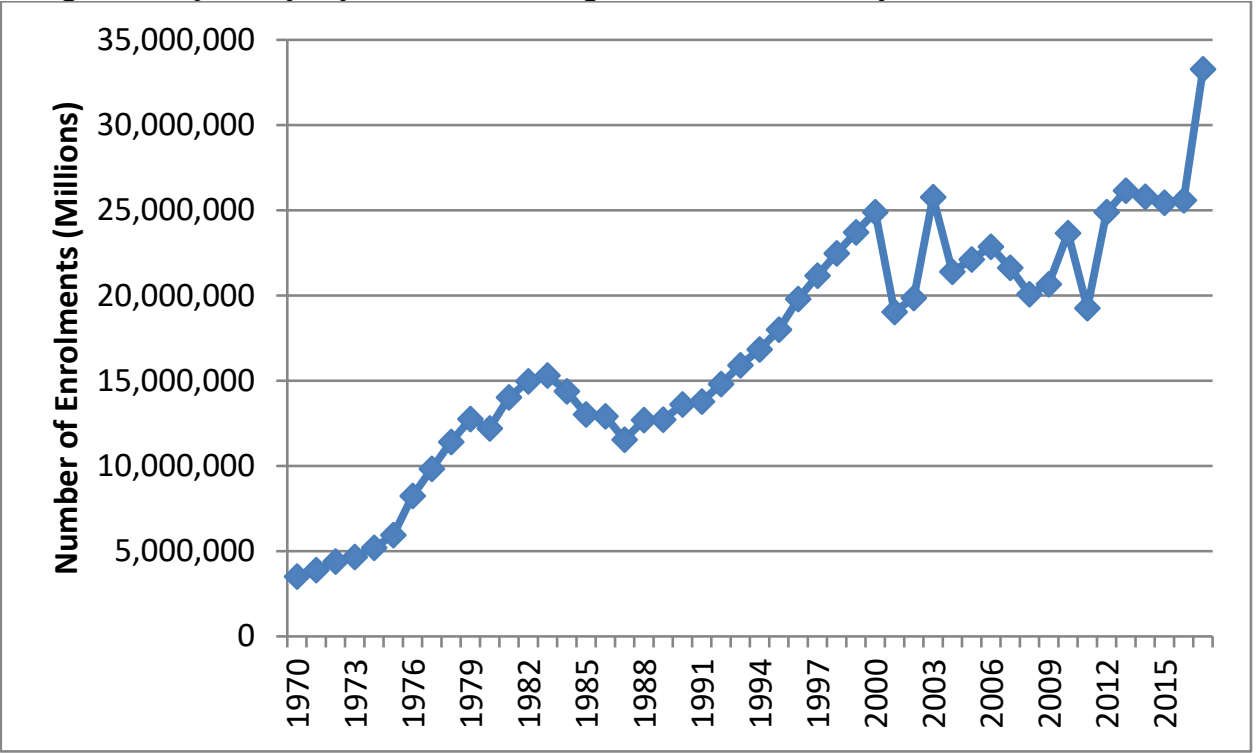

Figure 3: Primary School Pupils Enrolment in Nigeria, 1970 - 2017.

Source: Federal Ministry of Education (2018) 
By 1970, the student enrolment rate was 3,515,827(Figure 3)for all the states in Nigeria. The average student enrolment rate from 1971-1975 was 4,818,141. By 1980, 12,203,505 students were enrolled in primary schools, approximately 98 percent of this age group, up from 37 percent in 1970. In 1980, the level of enrolment in primary school was 12.2 million, which declined to 11.5million in 1987 (Federal Ministry of Education Report 2000). In 2010, primary school enrolment for Nigeria was $65.67 \%$. A total of 4,893,442 children were enrolled in Nigeria's public and private primary schools in 2012 . This had increased to 25.6 million by 2016 , according to the education ministry. In 2017, the student enrolment rate for primary school was 33,284,052 the highest enrolment figure from 1970 to 2017

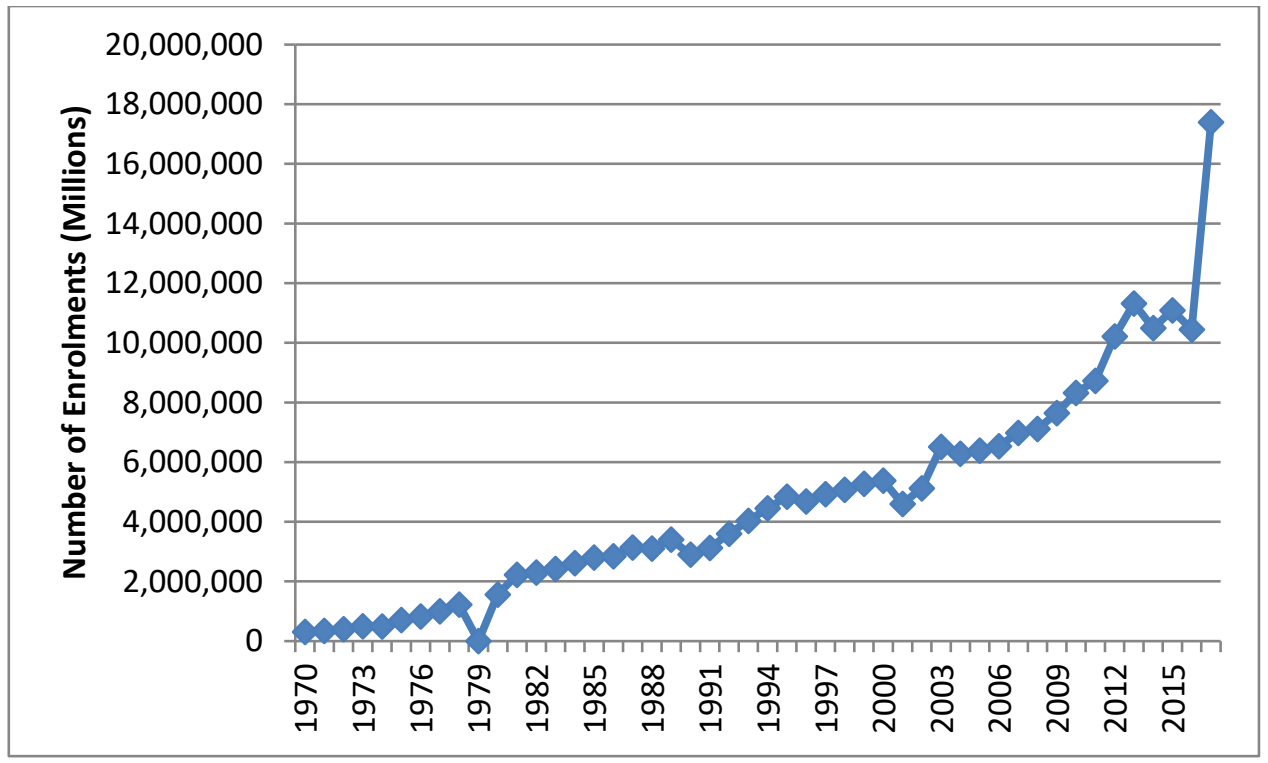

Figure 4: Secondary School Students Enrolment in Nigeria, 1970 - 2017.

Source: Federal Ministry of Education (2018)

Total enrolment in public and private secondary schools in Nigeria was 310,054 in 1970(Figure 4). The average growth from 1971to 1979 was 6.07 percent. Between 1971 and 1979, total secondary school enrolment decreased every year, reflecting a decline in the size of the school-age population over that period. From 1990, post-primary enrolment had risen steadily, reaching about 12 million in 2010 (Federal Ministry of Education Report 2012). The decline from 2011 to 2015 could partially be attributed to the insurgency by the terrorist group Boko Haram. But it was observed that enrolment in secondary schools was highest in 2017 when over 17.4 million pupils were registered (Federal Ministry of Education Report 2018).

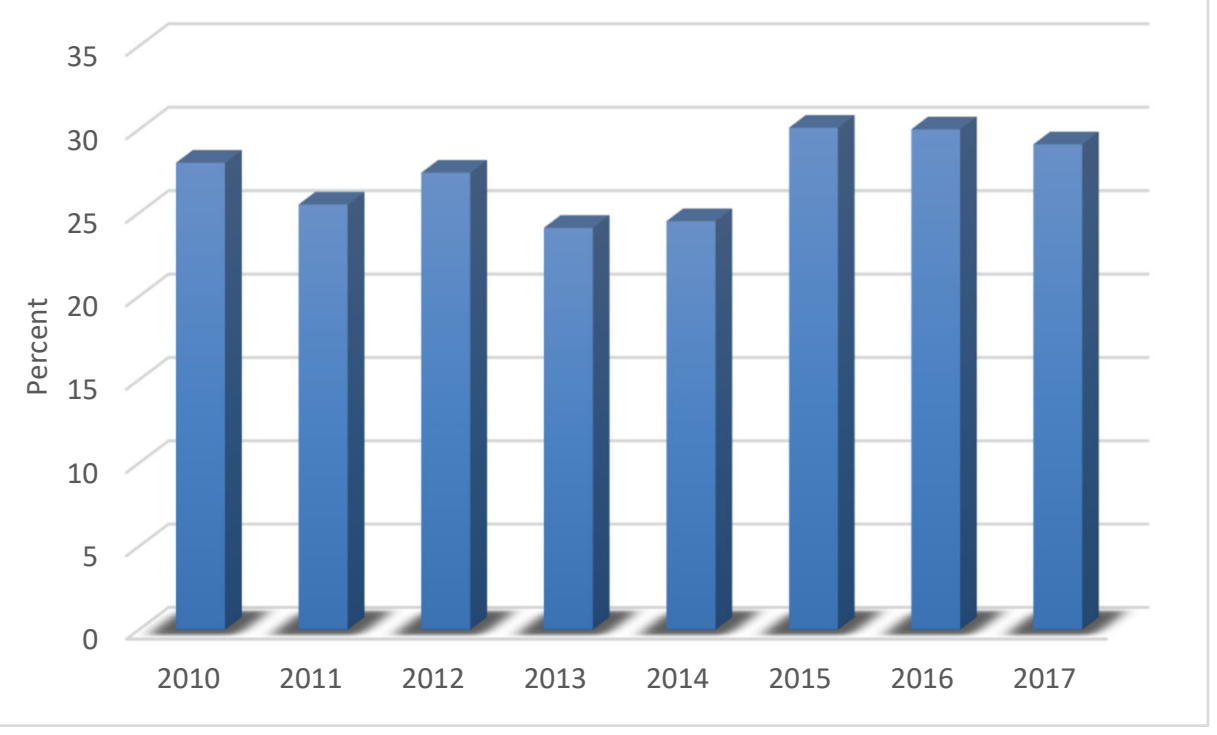

Figure 5: Proportion of Students Admitted from total applications into Tertiary schools in Nigeria.

Source: National Bureau of Statistics/Joint Admission and Matriculation Board,2018.

The proportion of students offered admission varied over the years with 28 per cent being offered admission 
in 2010 while the proportion of those admitted fell to 25.5 per cent in 2011(Figure 5). Further, a larger percentage of admission was recorded in the year 2015 with about 30 per cent of the applicants offered admission. Nigeria's higher education sector has been overburdened by strong population growth and a significant youth bulge.

\section{Literature Review}

As one of the core issues in the study of economic growth, the relationship between human capital and economic growth has drawn a lot of attention. However, Argument broadly exists in the academic circles. A lot of scholars believe that human capital and labour productivity has a significant positive relationship, placing a particular emphasis on the role of education on economic growth. Angel de la Fuente(2003)verified this relationship by using the Cobb Douglas production function and data from EU countries. The results show that with the average years of schooling for each additional year, the labour productivity in the EU countries was increased by $6.2 \%$ due to the promotion of scientific and technological progress, and the average years of schooling for each additional year may bring long-term economic growth of $3.1 \%$

Afroozet al. (2010) also examined the role of human capital on labour productivity in the food industries of Iran from 1995 to 2006. The results show that education has a positive and significant effect on labour productivity. Aggrey and Joseph's (2010) study of East African manufacturing firms shows that the average education level is positively associated with labour productivity. Using the panel data of 10 developed and 10 developing countries, Sonmez and Sener(2009)found that education and human capital contributes to economic growth in both developing and developed countries.

On the contrary, some scholars argue that human capital has no promoting effect on labour productivity (Krueger\&Lindahl,2001). Bils and Klenow(2000)claimed that the role of human capital is exaggerated, and the actual impact is not significant. Vandenbussch eetal (2006) studied the effect of different components of human capital, using data of 19 OECD countries during 1960-2000. Dividing the effect of human capital into two parts: imitation and innovation, he found that it was the human capital with higher education, rather than the average human capital, that had a significant promoting effect on total factor productivity (TFP) and also, the promoting effect of primary education in developed economies is not obvious.

Several empirical studies have also been carried out to further investigate the relationship between human capital and economic growth. For instance, Adeyemi and Ogunsola (2016) examined the impact of human capital development on economic growth in Nigeria using time series data spanning from 1980-2013 of secondary school enrolment, life expectancy rate, government expenditure on education, gross capital formation and economic growth. The authors adopted the ARDL cointegration approach in their study and their study revealed a positive long-run relationship among secondary school enrolment, life expectancy rate, government expenditure on education, gross capital formation and economic growth.

Olalekan (2014) evaluated the impact of human capital on economic growth in Nigeria using annual data on health and education, from 1980 to 2011. The study adopted the Generalized Method of Moment (GMM) techniques in the analysis and the estimated results provided evidence of a positive relationship between human capital and economic growth in Nigeria.

Oladeji (2015) investigated the relationship between human capital (through education and effective health care services) and economic growth in Nigeria, using annual time series data from 1980 to 2012. The study employed the Ordinary Lest Squares (OLS) methodology and revealed that there is a significant functional and institutional relationship between the investments in human capital and economic growth in Nigeria. The study found that a long-run relationship existed between education and economic growth in Nigeria.

Hadir and Lahrech, (2015) examined the relationship between human capital development and economic growth in Morocco using annual data from 1973 to 2011. The Ordinary Least Squares regression method was adopted using total government expenditure on health and education, the enrolment data of tertiary, secondary and primary schools as a proxy for human capital. The study revealed a positive relationship between total government expenditure on education, total government expenditure on health, primary school enrollment, secondary school enrollment, and tertiary school enrolment.

Jaiyeoba (2015) carried out an empirical investigation on the relationship between investment in education, health and economic growth in Nigeria, using time series data from 1982 to2011. He employed trend analysis, the Johansen cointegration and Ordinary Least Squares technique. Empirical findings, however, indicate that there is a long-run relationship between government expenditure on education, health, and economic growth. The variables: health and education expenditure, secondary and tertiary enrolment rate and gross fixed capital formation appear with the expected positive signs and are statistically significant (except government expenditure on education and primary enrolment rate).

Sulaiman, Bala, Tijani, Waziri, and Maji (2015) investigated the impact of human capital and technology on economic growth in Nigeria. They employed annual time series data for 35 years (1975-2010) and applied the autoregressive distributed lag approach to cointegration to examine the relationship between human capital, technology, and economic growth. Two proxies of human capital (secondary and tertiary school enrollments) were 
used in two separate models. Their result revealed that all the variables in the two separate models were cointegrated. Furthermore, the results of the two estimated models showed that human capital in the form of secondary and tertiary school enrollments have had a significant positive impact on economic growth. More so, technology also shows a significant positive impact on economic growth.

Borojo and Jiang (2015) analyzed the impact of education and health (human capital) on economic growth from 1980 to 2013 in Ethiopia. The human capital stock is proxied by primary, secondary and tertiary school enrolment. Human capital investment is proxied by expenditure on education and health. The Augmented DickeyFuller test and Johansen's Co-integration technique were used to test unit root and to validate co-integration among variables, respectively. Their study showed that public expenditure on health and education, primary and secondary school enrolment has a positive statistically significant effect on economic growth both in the long run and short run. Also, physical capital has a positive effect whilst inflation has a negative effect on economic growth. However, tertiary school enrolment has an insignificant effect on economic growth both in the long run and short run.

Ekesiobi, Dimnwobi, Ifebi, and Ibekilo (2016) examined public sector education investment and manufacturing output in Nigeria. The study employed Augmented Dickey-Fuller (ADF) unit root test and Ordinary Least Squares (OLS) technique to analyze the relationship between public educational spending, primary school enrolment rate, per capita income, exchange rate, foreign direct investment and manufacturing output growth. The study revealed that public education spending has a positive but insignificant effect on manufacturing output growth in Nigeria.

Lawanson (2015) investigated the relevance of education and health components of human capital to economic growth, using panel data from sixteen West African countries over the period 1980 to 2013 . He employed Diff-GMM dynamic panel technique. The empirical findings indicate that coefficients of both education and health have positive statistically significant effects on GDP per capita.

Ehimare, Ogaga-Oghene, Obarisiagbon, and Okorie (2014) investigated the Nigerian government expenditure on human capital development. The level of human capital development, which is a reflection of the level of health and education of a nation affect the level of economic activities in that nation. The unit root test was conducted to determine whether the variables are stationary or not using Phillip Peron test. To capture the efficiency of government expenditure on human capital development in Nigeria, the data analysis was conducted using Data Envelopment Analysis involving Input Oriented Variable Return to Scale. The findings of the study revealed that there has been a significant reduction in the efficiency of government expenditure from 1990 up till 2011 which has been decreasing.

The moderating effect of economic complexity on the contribution of human capital to economic growth was recently examined by $\mathrm{Zhu}$ and $\mathrm{Li}$ (2017). They find a positive interaction effect, suggesting that economic complexity reinforces the effect of human capital on growth. This study, therefore, contributes in filling the gap in the existing literature by examining the potential mechanisms on the levels of education and health impacts on economic growth in Nigeria, which helps to explain the large heterogeneity of findings by previous studies.

\section{Methodology}

\subsection{Theoretical Model}

Using Cobb-Douglas production function, we can construct a Solow model which includes human capital: $Y=A K^{\alpha} H^{1-\alpha}$

wherein, $Y$ represents the total output; $A$ represents technology stock; $K$ represents physical capital stock; $H$ is human capital stock, which is composed of two parts: education capital $E$ and health capital $M$.

$H=E^{\lambda} M^{1-\lambda}$

wherein, $\lambda$ is a parameter, and in the process of generating human capital.

We can transform (1) to:

$\operatorname{In}(Y / L)=\operatorname{In} A+\alpha \operatorname{In}(K / L)+(1-\alpha) \operatorname{In}(H / L)$

$\operatorname{In} y=\operatorname{In} A+\alpha \operatorname{In} k+(1-\alpha) \operatorname{In} h$

wherein, $y$ represents the per capita GDP; $k$ is physical capital per capita and $h$ represents per capita human capital, composed by the average years of schooling and life expectancy.

$h=\left(\mathrm{e}^{\theta 1 S 1} \mathrm{e}^{\theta 2 S 2} \mathrm{e}^{\theta 3 S 3}\right)^{\lambda} m^{1-\lambda}$

substitute equation (4) into (3), and presented in econometric form, we have:

$\operatorname{In} y_{t}=\operatorname{In} A+\alpha \operatorname{In} k_{t}+(1-\alpha)(1-\lambda) \operatorname{In} m_{t}+(1-\alpha)\left(\lambda \theta_{1} S_{1 \mathrm{t}}+\lambda \theta_{2} S_{2 \mathrm{t}}+\lambda \theta_{3} S_{3 \mathrm{t}}\right)+\varepsilon_{\mathrm{t}}(5)$

Where $\operatorname{lnm}$ represents per capita health, $\left(\theta_{\mathrm{i}}\right.$ represents the coefficient of the ith level of education; Si represents the $i$-th level of education, $i=(1,2,3)$, respectively represents the level of primary, secondary and higher education), and $\varepsilon_{\mathrm{t}}$ is the error term while $\mathrm{t}$ is the time.

This article hypothesises that human capital is positively related to economic growth. And as the two most important components of human capital, both education capital and health capital have a significant positive effect 
on economic growth.

\subsection{Data and Sources}

This paper used an annual dataset from 1970 to 2017. Annual time-series data used in this study were obtained from the National Bureau of Statistics, for real GDP, growth of agriculture GDP and population size (for the labour force of population growth). Data on health and education measures such as life expectancy at birth and average years of schooling, respectively, were taken from the World Development Indicators (World Bank, 2018) database. Gross enrolments for primary, secondary, and tertiary education levels, were obtained from the Federal Ministry of Education (FME, 2018) Nigeria.

\subsection{Estimation Procedure}

First, the times series properties of the variables used in the model were investigated to confirm their order of integration to avoid spurious regression using Augmented Dicky Fuller(ADF) (1979) and Philip Peron (PP) (1988) to allow for robustness. The test for unit root for a series is carried out using the following equation:

$\Delta X_{t=\alpha_{0}}+\alpha_{1 t}+\alpha_{2} \sum_{i=0}^{n} \lambda_{i} \Delta X_{t-i}+\varepsilon_{t}(6)$

Where $\alpha_{0}, \alpha_{1 \mathrm{t}}, \alpha_{2}$ and $\lambda_{1} . \lambda_{\mathrm{p}}$ are parameters to be estimated while $\varepsilon_{\mathrm{t}}$ is the error term, which is assumed to be normally and identically distributed. Immediately after the above, a co-integration test was carried out using the Johansen co-integration test procedure, and this was followed by estimation of the Two-Stage Least Squares (2SLS) regression technique. This technique is an extension of the OLS method. It is used when the dependent variable's error terms are correlated with the independent variables. Additionally, it is useful when there are feedback loops in the model, it provides consistent and efficient estimates of a regression.2SLS estimator does not require that the observed variables come from normal distributions, and it is less sensitive to specification errors that the full information estimators. As such, this makes the 2SLS estimator a useful complementary estimator to the other full information estimators.

\section{Empirical Results}

\subsection{Unit Root Tests}

Standard econometric methodologies assume stationarity in the time series while they are in the real sense nonstationary. Hence the usual statistical tests are likely to be inappropriate and the inferences drawn are likely to be erroneous and misleading (Dauda, 2010). The essence of testing for unit root is because if the series is not stationary then all the results from the classical linear regression analysis are not valid. From the results below, the model used is not spurious i.e the variables are stationary since the ADF and PP values are greater than the critical values of the variables, in absolute terms. The outcome of the test suggests that life expectancy and primary school enrolment rate were stationary at levels, while other variables were stationary after first difference.

Table 1: Results of Unit Roots Tests using ADF and PP Approaches.

\begin{tabular}{|l|l|l|l|l|l|}
\hline Series & ADF & Critical value @ $0 \%$ & PP & Critical value $@ 5 \%$ & Order of Integration \\
\hline GDP & -5.0302 & -2.9281 & -5.1963 & -2.9281 & $1(1)$ \\
\hline CAPITAL & -3.8784 & -2.9571 & -4.6191 & -2.9511 & $1(1)$ \\
\hline LIFE & -3.6849 & -2.9297 & -3.3147 & -2.9266 & $1(0)$ \\
\hline SCHOOLING & -3.5338 & -2.9964 & -3.698 & -2.9484 & $1(1)$ \\
\hline PRY & -3.1396 & -2.9266 & -3.2509 & -2.9266 & $1(0)$ \\
\hline SEC & -11.142 & -2.9281 & -3.6976 & 2.92662 & $1(1)$ \\
\hline TERTIARY & -6.2176 & -2.9332 & -6.2174 & -2.9332 & $1(1)$ \\
\hline
\end{tabular}

Sources: Authors' compilation from Eviews 9 output.

\subsection{Cointegration test}

Having tested the stationarity of each time series, the next step is to test for cointegration between the variables. The Johansen procedure is used to identify the long-run relationship among the variables. Cointegration of the dependent variable with the independent variables forms a dynamic basis through which forecast can be made. The table below shows that the dependent variable GDP is cointegrated with the independent variables. The trace statistics is greater than the critical values at 5\% level of significance for at least 3 equations; this indicates a rejection of the null hypothesis of no cointegration in favour of three cointegration relationships between the variables. The result further explains that there is a long-run relationship between the variables. 
Table 2: Result of Johansen Cointegration Test.

\begin{tabular}{l|l|l|l|l}
\hline $\begin{array}{c}\text { Hypothesized } \\
\text { No. of CE(s) }\end{array}$ & Eigen value & Trace Statistic & $5 \%$ Critical Value & Prob. \\
\hline \hline None $*$ & & & & \\
At most 1 $*$ & 0.935607 & 242.8341 & 125.6154 & 0.0000 \\
At most 2 & 0.888907 & 157.8090 & 65.75366 & 0.0000 \\
At most 3 & 0.460541 & 46.60174 & 47.85613 & 0.0006 \\
At most 4 & 0.399689 & 27.46892 & 29.79707 & 0.0653 \\
At most 5 & 0.231218 & 11.64937 & 15.49471 & 0.0907 \\
At most 6 & 0.106704 & 3.497970 & 3.841466 & 0.1745 \\
\hline
\end{tabular}

Note: Trace test indicates 3 cointegrating equations at 0.05 level, * denotes rejection of the hypothesis at the 0.05 level.

Sources: Authors' compilation from Eviews 9 output.

\subsection{Results of Two-Stage Least Squares (2SLS) Analysis}

For Two-Stage Least Squares regression, the lagged endogenous explanatory variables are chosen as instrumental variables. On one hand, it can ensure that the endogenous explanatory variables are related to instrumental variables. On the other hands, since the lagged variable,s have already occurred, therefore its value has been determined for the current period, and it is not related to the disturbance term of the current period. The estimated results are presented below.

Table 3: Economic Growth Model with Average Years of Schooling.

\begin{tabular}{l|l|l|l|l}
\hline Variable & Coefficient & Std. Error & t-Statistic & Prob. \\
\hline \hline CAPITAL & 0.12175 & 0.04711 & 2.58442 & 0.0145 \\
LIFE & 0.08674 & 0.0307 & 2.82594 & 0.0081 \\
SCHOOLING & 0.02835 & 0.05757 & 0.49244 & 0.6258 \\
\hline R-squared & 0.75308 & & F-statistic & 86.6746 \\
Adjusted R-squared & 0.70014 & Prob(F-statistic) & 0.0008 \\
S.E. of regression & 0.17114 & & D-W stat & 1.86407 \\
\hline
\end{tabular}

Sources: Authors' compilation from Eviews 9 output.

An examination of the econometric results in Table 3showsw that the overall fit of the estimated model is satisfactory with an R-squared of 0.75 . Thus, $75 \%$ of the systematic variation in economic growth is explained by the explanatory variables, while the remaining $25 \%$ is explained by other factors, captured by the error term and not included in the model. The F-statistic of 86.6 is significant at the $1 \%$ level indicating a significant relationship between economic growth and the explanatory variables taken together. From Table 3, physical capital and life expectancy had a significant positive effect on economic growth, whereas, average years of schooling had a positive but insignificant effect on economic growth. On average, a percentage rise in physical capital, life expectancy and average years of schooling will cause economic growth to rise by $0.12,0.09$ and 0.03 percents, respectively.

Table 4:Economic Growth Model with different levels of education.

\begin{tabular}{l|l|l|l|l}
\hline Variable & Coefficient & Std. Error & t-Statistic & Prob. \\
\hline \hline CAPITAL & 0.26917 & 0.12089 & 2.22652 & 0.0345 \\
LIFE & 0.20784 & 0.13998 & 2.81394 & 0.009 \\
PRY & -0.011 & 0.16059 & -0.0683 & 0.9461 \\
SEC & 0.21697 & 0.23546 & 3.89433 & 0.0006 \\
TERTIARY & 0.25112 & 0.10195 & 2.4633 & 0.0204 \\
\hline R-squared & 0.94567 & & F-statistic & 96.3548 \\
Adjusted R-squared & 0.93763 & & Prob(F-statistic) & 0 \\
S.E. of regression & 0.14127 & & D-W stat & 1.73405 \\
\hline
\end{tabular}

Sources: Authors' compilation from Eviews 9 output.

Table 4 provides the results of the estimated model with different levels of education. The R-squared value indicates that about 94 percent of the variations in economic growth in Nigeria were explained by the explanatory variables. The F-value is highly significant and a hypothesis of a log-linear relationship between economic growth and the explanatory variables cannot be rejected at the one percent level. All the coefficients have the expected signs and were significant except primary education coefficient that has a negative sign and not significant. On average, a percent increase in physical capital, life expectancy, secondary and tertiary school enrolment rates will lead to $0.27,0.21,0.22$ and 0.25 percent increase in economic growth, respectively. Contrarily, a percent increase in primary school enrolment rate will cause economic growth to reduce by 0.01 percent. 


\section{Conclusion and Recommendations}

Based on our empirical findings, physical and human capital showed a significant positive correlation with economic growth in Nigeria. The empirical results suggest that physical capital is an important determinant of economic growth in line with both the classical and new growth theories. Life expectancy, an important part of human capital, have a significant positive impact on the economic growth of Nigeria. This reflects the fact that healthier people can work longer hours, and they are more abundant and stronger in physical, mental or cognitive abilities, which directly improves labour productivity and economic growth. There is a threshold effect on the relationship between education - another component of human capital - and economic growth in Nigeria. The results show that average years of schooling and primary education do not have a significant positive impact on economic growth while secondary and higher education has a significant positive effect on economic growth. This may be because workers with higher education can better master new technology and have a more innovative ability, which is extremely meaningful in today's world. Therefore, the higher the level of education the more beneficial it becomes for the economic growth of the country.

From the foregoing, therefore, to promote rapid economic growth in Nigeria, all levels of government should raise the percentage of educational funds in their financial disbursement, optimize education expenditure structure and improve fund utilizing efficiency. The government must build a sound system of health care to promote the development of health capital since it is an important determinant for economic growth in Nigeria. Government should pay attention to all levels of education in the country, particularly, the secondary and higher education so that more teenagers can receive higher education and avoid entering the labour market too early. Only in that way we can increase the proportion of labour force with higher education, and finally promote the economic development of Nigeria. High-quality primary education and secondary education is the premise of high-quality higher education. Therefore, the government should take a clear responsibility in this process and gradually increase the proportion of financial education funds.

\section{Acknowledgments}

The author is grateful to Dr Igbinedion S.O, Department of Economics, University of Benin for insightful comments

\section{REFERENCES}

Adeyemi, P. A. \&Ogunsola, A. J. (2016). The impact of human capital development on economic growth in Nigeria: ARDL approach. IOSR Journal of Humanities and Social Science, 21 (3), 17-27.

Afrooz, A., Rahim, K. B. A., Noor, Z. B. M. \& Chin, L. (2010). Human capital and labour productivity in the food industries of Iran. International Journal of Economics \& Finance, 2, 47-51.

Aggrey, N. \& Joseph, L. E. S. (2010). Human capital and labour productivity in East African manufacturing firms. Current Research Journal of Economic Theory, 2, 48-54.

Bhatia, R. J.\&Engström, P. (1972).Nigeria's Second National Development Plan: A financial analysis (Second Plan National de Développement du Nigéria: analysefinancière) (El Segundo Plan Nacional de Desarrollo de Nigeria: Un análisisfinanciero) Palgrave Macmillan Journals on behalf of the International Monetary Fund,19(1), 145-173. DOI: 10.2307/3866443

Benhabib, J. \& Spiegel, M. (2005). Human capital and technology diffusion. Handbook of Economic Growth, 1, 935-966.

Bils, M. \&Klenow, P. J. (2000). Does schooling cause growth? American Economic Review, 90, 1160-1183.

Borojo, D. G. \& Jiang, Y. (2015). The impact of Africa-China trade openness on technology transfer and economic growth for Africa: A dynamic panel data approach. Annals of Economics and Finance, 17 (2) 403-431.

Dauda, R.O. (2009). Investment in education and economic growth In Nigeria: A co-integration approach. Paper presented at the 9th Global Conference on Business and Economics held at University of Cambridge, UK. (55) $158-169$.

De la Fuente, Á. (2003). Human capital in a global and knowledge-based economy. Part 2. assessment at the EU country level. Recercat Principal.

Dickey, D.A., \& Fuller, W.A. ((1979). Distribution for the estimates for autoregressive time series with a unit root. Journal of the American Statistical Association, 74, 427-431.

Ekanem, F. E. (2012). Education for Self-Reliance: An imperative for national development.African Journal of Philosophy. 14 (1), 162-166.

Ehimare, O. A., Ogaga-Oghene, J. O., Obarisiagbon, E. I. \&Okorie, E. U. (2014). The Nigerian government expenditure on human capital development: An efficiency analysis. European Journal of Business and Social Sciences, 3 (7), 1-13.

Ekesiobi, C. S., Dimnwobi, S. K., Ifebi, O. E. \&Ibekiol, B. N. (2015). Public sector education investment and manufacturing output in Nigeria: Empirics and policy options. Public Policy and Administration Research, 6 (7), $89-102$. 
Hadir, M. A. \&Lahrech, A. (2015). The human capital development and economic growth in Morocco. Quarterly Journal of Economics, 107(2), 407-437.

Hua, P. (2005). The Effects of different educational levels on the growth of total factor productivity: An empirical study from China's provinces. Economics, 10, 147-165.

Institute of International Education, (2017). A number of international students in the United States. 1075, Diplomatic Drive, Central Business Area, Nigeria.

Jaiyeoba, S. V. (2015). Human capital investment and economic growth in Nigeria. African Research Review, 9(1), $30-46$.

Krueger, A. B. \&Lindahl, M. (2001). Education for growth: Why and for whom? Journal of Economic Literature, 39, 1101-1136.

Lawanson, A. O. (2015). Economic growth experience of West African region: Does human capital matter? International Journal of Business and Social Science. 6 (12), 127-137.

Lucas, S. R. (1988). The mechanics of economic development. Journal of Monetary Economics, 22(1), 30-42.

Mayer-Foulkes, D. (2001). The long-term impact of health on economic growth in Latin America. World Development, 29 (6), 1025-33.

National Bureau of Statistics (2017), Series of statistical reports, Abuja. Retrieved from https://www.nigerianstat,gov.ng

Ogundari, K.\&Awokuse, T. (2018). Human capital contribution to economic growth in Sub Saharan Africa: Does health status matter more than education? Economic Analysis and Policy, 58, 131-140.

Oladeji, A. O. (2015). Impact of human capital development on economic growth in Nigeria. International Journal of Recent Research in Commerce Economics and Management, 2(2), 151-164.

Olalekan, O. (2014). Human capital and economic growth in Nigeria. International Journal of Innovation and Scientific Research, 11(2), 291-294.

Phillips, P.C.B., \&Perron, P. (1988). Testing for a unit root in time series regression. Biometrica, 75, 335-346.

Romer, P. (1986). Increasing returns and long-run growth. Journal of Political Economy,94(5), 1002-1037.

Sonmez, F. D. \&Sener, P. (2009). Effects of human capital and openness on the economic growth of developed and developing countries: A panel data analysis. World Academy of Science, Engineering and Technology, $30,1242-1246$.

Soto, M. \& Cohen, D. (2007). Growth and human capital: Good data, good results. Journal of Economic Growth, $12,51-76$

Sulaiman, C., Bala, U., Tijani, B. A., Waziri, S. I. \&Maji, I. K. (2015). Human capital, technology, and economic growth: Evidence from Nigeria. SAGE Open, 5(4), $102-123$.

Temple, J. R. W. (2001). Generalizations that aren't? Evidence of education and growth. European Economic Review, 45, 905-918.

Vandenbussche, J., Aghion, P. \&Meghir, C. (2006). Growth, distance to frontier and composition of human capital, Journal of Economic Growth, 11, 97-127.

Wolff, E. N. (2000). Human capital investment and economic growth: Exploring the cross-country evidence. Structural Change and Economic Dynamics, 11, 433-472.

World Bank. (2017). World development indicator, World Bank, Washington, DC Retrieved from https://datacatalog.worldbank.org/dataset/world-development-indicators.

World Bank Data. (2018). World Bank open data. Retrieved from https://data.worldbank.org/

Zhu, S. \&Renyu, L. (2017). Economic complexity, human capital and economic growth: Empirical research based on cross-country panel data. Applied Economics, 49, 3815-28. 